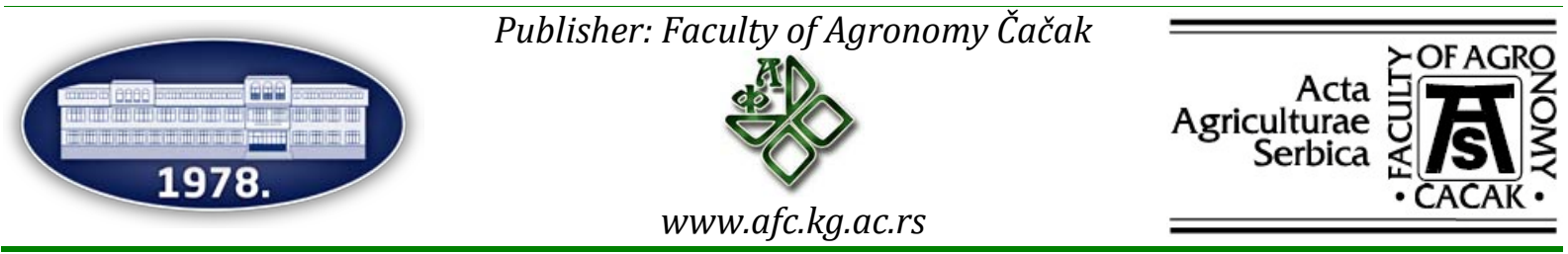

\title{
Planting scale effect as the indicator of sesame yield under coastal conditions
}

\author{
Muhammad Hakeem ${ }^{1}$, Muhammad Waseem ${ }^{1 *}$, Dost Mohammad Baloch ${ }^{1}$, Ghulam Khaliq ${ }^{1}$, \\ Shahab Anwer ${ }^{1}$, Muhammad Tahir ${ }^{2}$, Qurban Ali ${ }^{3}$, Mustajab A. Khan ${ }^{4}$
}

${ }^{1}$ Lasbela University of Agriculture, Water and Marine Science, Uthal, Lasbela, Pakistan

2 Department of Agronomy, University of Agriculture Faisalabad

${ }^{3}$ Institute of Molecualr Biology and Biotechnology, The University of Lahore, Lahore, Pakistan

${ }^{4}$ Baluchistan Agriculture College, Quetta, Baluchistan

*Corresponding author: waseem_1028@yahoo.com

Received 5 November 2019; Accepted 4 February 2020

\begin{abstract}
A B S T R A C T
A field experiment was conducted to evaluate the effect of planting scale on sesame yield under coastal conditions during 2016 at the Lasbela University of Agriculture, Water and Marine Science, Uthal, Balochistan. The trial treatment included three sesame varieties i.e. SV1 ('TS-5'), SV2 ('TH-6') and SV3 ('4002') grown at three sowing dates at 15 days' intervals, S1 = 1st sowing (15 March 2016), S2 = 2nd sowing (1 April 2016) and S3 = 3rd sowing (15 April 2016). The results of various growth and yield attributes were found to be significant, and a non-significant interaction was found for sowing dates and sesame genotypes. Maximum yield was observed at S3= 3rd sowing date (15 April 2016) for SV1 ('TS-5') under the applied treatment. Testing under the coastal environmental conditions of the Lasbela District suggested that maximum seed weight was obtained by planting the sesame variety 'TS-5' on 15 April 2016.
\end{abstract}

Keywords: capsule, correlation, sowing date, sesame cultivars.

\section{И 3 В О Д}

Експеримент је спроведен са циљем да испита утицај времена сетве на принос сезама у приобалним условима током 2016. године на Универзитету за пољопривреду, воду и море у Ласбели, Утхал, Балохистан. Испитиване су три сорте сезама, СВ1 ('ТC-5'), СВ2 ('ТХ-6') и СВ3 ('4002') посејане у интервалима од 15 дана, С1 = 1. сетва (15. март 2016$)$, С2 = 2. сетва (1. април 2016) и С3 = 3. сетва (15. април 2016). Утврђен је значајан утицај на различите параметаре пораста биљке и приноса, док интеракција између датума сетве и генотипова сезама није била значајна. Максимални принос забележен је на С3 = 3. датум сетве (15. април 2016.) за СВ1 ('ТC-5'). Испитивање у приобалним окружењем округа Ласбела указало је да је максимална маса семена добијена сетвом сорте сезама „ТС-5“ 15. априла 2016.

Кључне речи: махуна, корелација, датум сетве, сорте сезама.

\section{Introduction}

Sesame is one of the oldest crops in Asia, grown for more than 5000 years (Anandkumar and Pandian., 2001; Bhardwaj, 2014). Sesame (Sesamum indicum L.) is one of the oldest cultivated oil crops in the world. China and India are the world's largest producers of sesame crops, followed by Burma, Sudan, Nigeria, Uganda, Venezuela, Mexico, Turkey and Ethiopia. In Ethiopia sesame grows well in the lowlands either as a sole crop or intercropped. Sesame can grow well in lowland/humid areas at an altitude of up to $1,250 \mathrm{~m}$ under rain-fed conditions (De, 2013; Mkamil and Bedigian, 2007). Regardless of its nutritional value and medicinal significance, the average productivity of this essential oil seed crop of India is $342 \mathrm{~kg}$ of seed ha-1, which is far below the average productivity of China (1487 kg ha-1) and Egypt (1333 kg ha-1) (FAO, 2013).

Sesame is an annual, natural pollinated indeterminate short-day plant, usually flowering during 43-46 days after sowing (Jan et al., 2014). In
Pakistan sesame is grown on 84,000 hectares of land, with a production of 35,000 tons. Sesame production is not sufficient to meet the national demands of edible oil. Pakistan spends US \$ 1354 million on edible oil imports. Pakistan ranks $22^{\text {nd }}$ in global sesame production, with a share of $0.7 \%$. In Pakistan, the production of sesame is $1200 \mathrm{~kg} \mathrm{ha}^{-1}$, but average yield is $452 \mathrm{~kg} \mathrm{ha}^{-1}$, and Pakistan ranks $58^{\text {th }}$ in terms of yield, which is very low. Yield gap is $750 \mathrm{~kg} \mathrm{ha}^{-1}$, which is due to meager agro-management practices (GOP, 2014).

Sesame sowing is not dependent on rainwater since yield is affected by sowing date and variety characteristics in response to $\mathrm{N}$ application at the agroclimatic conditions of Peshawar (Ali and Jan, 2014). The productivity of sesame is low both in Ethiopia and other major growing countries due to poor farming practices and use of local varieties. Even though these countries have good environmental conditions for sesame cultivation, the production is carried out mostly under small-scale and rain-fed conditions. The major production constraints in Ethiopia are lack of new 
technology and improved varieties, and inappropriate use of fertilizers and pesticides (Hamza and Abd ElSalam 2015; Tsehay, 2006).

Nitrogen has the most pronounced effect on plant development and yield. In sesame, nitrogen plays a very important role in protein combination as part of chlorophyll and enzymes. About $45 \mathrm{~kg} \mathrm{~N}^{\mathrm{N}} \mathrm{a}^{-1}$ improved the yield of sesame. Results showed that planting sesame at a distance of $104 \mathrm{~cm}$ using nitrogen at the rate of $90 \mathrm{~kg} \mathrm{ha}^{-1}$ produced the maximum amount of capsules per plant and yield per hectare (Abeje et al., 2016; Malik et al., 2003; Olowe and Adeoniregun, 2010). Agronomic practices showed that planting density influenced the maturity and yield of sesame (Chongdar et al., 2015; Grichar et al., 2001; Nantongo, 2002). Yield of sesame differed due to planting space and plant height. Intra-row spacing of $12 \mathrm{~cm}$ gave maximum capsule weight per plant and 1000-seed weight (Haruna, 2011).

Yield response of different sesame (Sesamum indicum L.) varieties to plant spacing under irrigated conditions needs to be known for practical purposes, as planting density is a major management variable used in matching crop requirements to the environmental offer of resources. Maximum yield of sesame can be achieved from the best spatial arrangement of plants for effective canopy development, water and nutrient utilization, pest control and little weed crop competition (Boureima et al., 2011; Ball et al., 2000; Gebre, 2006 and Wei et al., 2008).

Planting method is an important aspect of advanced production technology which not only ensures better crop establishment but also results in water saving when the crop is sown on ridges.. Sowing of sesame crop on ridges spaced $70 \mathrm{~cm}$ apart at a $10 \mathrm{~cm}$ distance between hills gave highest values for number of capsules plant ${ }^{-1}$, seed weight plant ${ }^{-1}$ and 1000 -seed weight. In the same way $\mathrm{N}$ fertilization has to be detailed to determine a suitable $\mathrm{N}$ level for sesame crop to harvest its highest potential under Faisalabad environment (Malik et al., 2003). Sesame seed is very nutritious and imperative raw material for the confectionery industry. Seeds with hulls are rich in calcium $(1.3 \%)$ and provide a valuable source of minerals (Onsaard, 2012).

Different sesame varieties have different branching habits, some of them are more branching and others are less branching. Plant geometry is one of the most important components of systematic cultivation and manipulations that could increase yield performance. Due to proper space, plants can gain sufficient sunlight, water and nutrition from the soil, which ensures their healthy yield. A field experiment was conducted to assess the effect of planting scale on sesame yield under coastal conditions.

\section{Material and methods}

The field study was conducted on sesame oil seed crop in 2016 at an agronomy research area near the Faculty of Agriculture LUAWMS, Uthal, Balochistan. The experiment was carried out to determine the effect of planting scale on sesame yield under coastal conditions. The chemical analysis of the experimental soil was carried out before plantation and after harvesting. The experimental soil was loamy in texture with a slightly alkaline $\mathrm{pH}$, as given in Table 1 .

Table 1

Chemical analysis of soil sample before sowing of the crop

\begin{tabular}{|c|c|c|c|}
\hline Sr. No. & Determination & Unit & Value \\
\hline 1 & $\mathrm{pH}$ & - & 7.8 \\
\hline 2 & $\mathrm{EC}$ & $\mathrm{D} \mathrm{S} \mathrm{m}^{-1}$ & 1.55 \\
\hline 3 & $\mathrm{~N}$ & $\%$ & 0.44 \\
\hline 4 & $\mathrm{P}$ & $\mathrm{ppm}$ & 1.61 \\
\hline 5 & $\mathrm{~K}$ & $\mathrm{ppm}$ & 0.23 \\
\hline 6 & $\mathrm{OM}$ & $\%$ & 0.30 \\
\hline
\end{tabular}

The experimental design was RCBD with a factorial arrangement with three replicates. The plot size $3 \mathrm{~m} \mathrm{x}$ $5 \mathrm{~m}$ was used for the experiment. Three varieties of sesame (SV $1=$ 'TS-5', SV2 = 'TH-6', SV $3=$ '4002') were used in the experiment, which were planted at 3 different sowing dates $\left(\mathrm{S}_{1}=15\right.$ March 2016, $\mathrm{S}_{2}=1$ April 2016, $S_{3}=15$ April 2016) with an interval of 15 days. Irrigation was applied before sowing of he crop. At optimum field capacity, a simple cultivator was used for seedbed preparation and flat sowing method was used for planting. The crop was cultivated in a wellprepared seed bed. Row to row distance and plant to plant distance were $45 \mathrm{~cm}$ and $15 \mathrm{~cm}$, respectively. Each of the three treatments received the suggested uniform dose of fertilizer ( $\mathrm{N}$ and $\mathrm{P}$ ) at the rate of $60 \mathrm{~N}$ and $\mathrm{P}$ ha1. During cultivation, the plant to plant and row to row distances were maintained with a dibbler. Before sowing, a uniform dose of phosphorus fertilizer (DAP at the rate $60 \mathrm{kgha}^{-1}$ ) was used while half of the nitrogen fertilizer in the form of urea was applied with the 1st irrigation in each treatment. The left over dose of nitrogen fertilizer was applied in two different splits, the $1^{\text {st }}$ dose after 30 days and the remaining amount at flowering. After the $1^{\text {st }}$ irrigation, the crops were irrigated at an interval of 8 to 24 days till crop maturity, depending upon the crop requirement and climatic conditions. Weeds were controlled manually by hoeing. During the growth period, the insecticide Icon at the rate 10CS was sprayed. All the other agronomic practices were carried out uniformly. Climate data of the site was obtained from the Meteorological Department during the whole crop season. The crop was harvested on 12 October 2016.

The following parameters i.e. plant height at maturity $(\mathrm{cm})$, No. of capsules / plant, No. of seeds / capsule, Leaves per plant, Stem diameter, Productive capsules per plant, Unproductive capsules per plant and Seed weight ( $\mathrm{t} \mathrm{ha}^{-1}$ ) were recorded by using standard procedures during the growing season. The data gathered on different yield and growth parameters was analyzed statistically using Fisher's testing of difference method and the lest significant difference (LSD) analysis at 5\% probability level to analyze the difference between treatment means (Steel et al., 1997). During the whole crop season, monthly climate data, Figure 1(a, b, c, d and e), were obtained fromthe Meteorological Department situated in the vicinity of Lasbela University. 


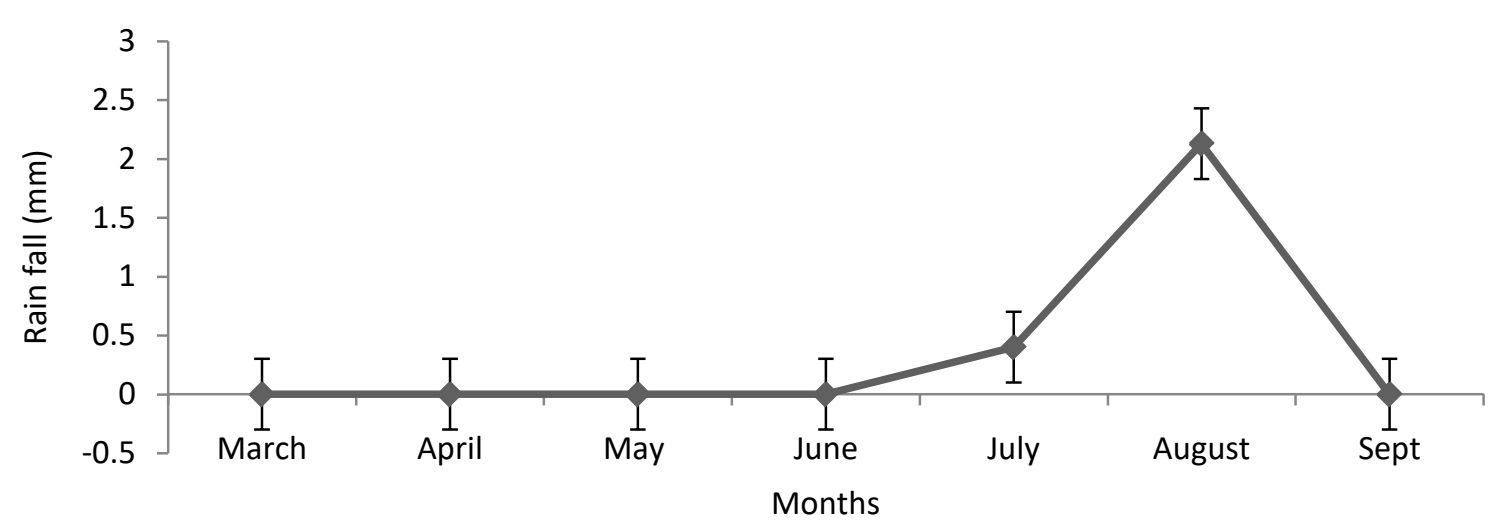

Figure 1a. Rainfall variations during the cropping season in 2016

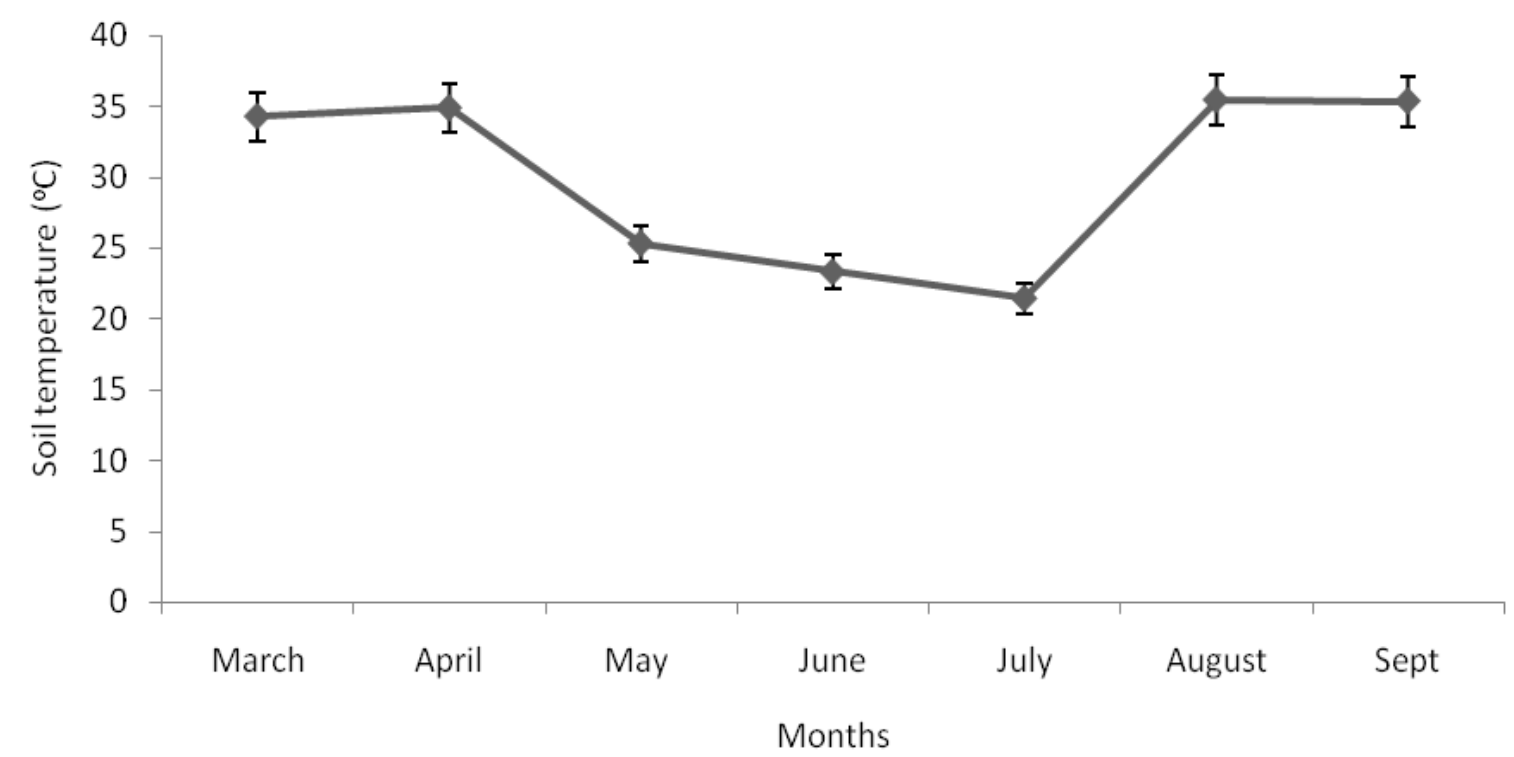

Figure 1b. Soil temperature variability during the experimental season 2016

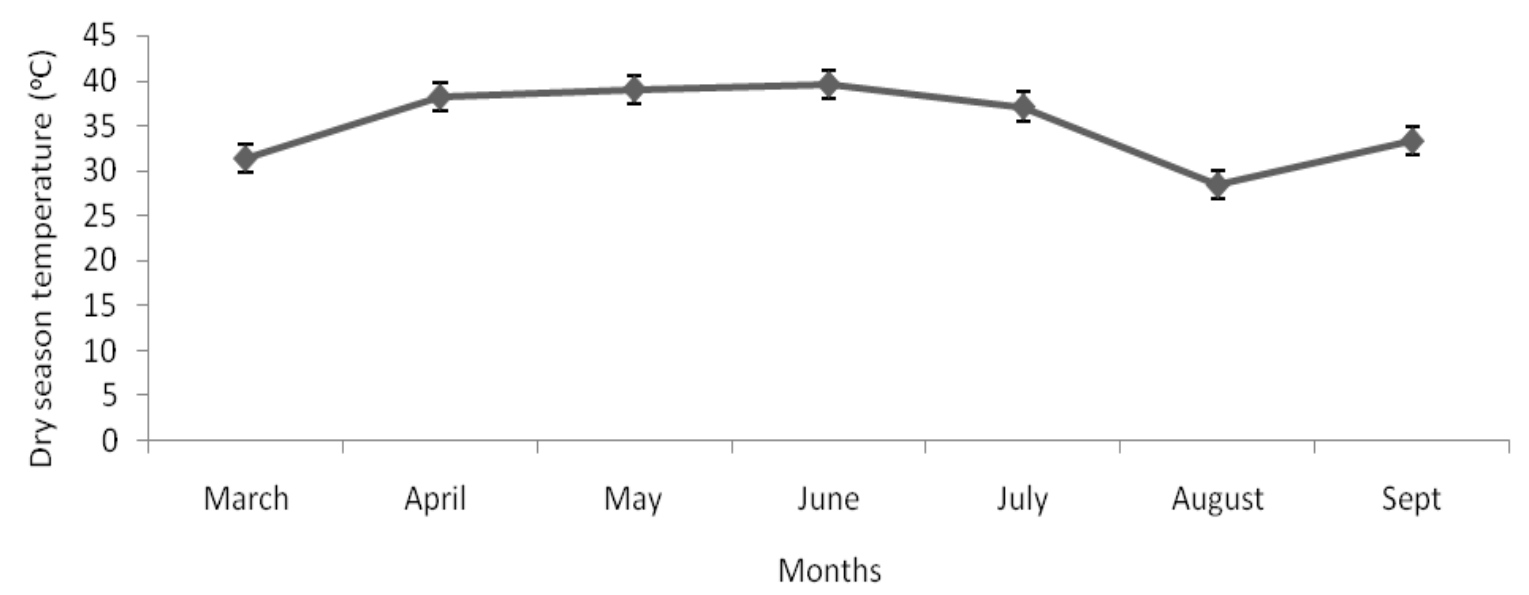

Figure 1c. Dryness data during the experiment in 2016 


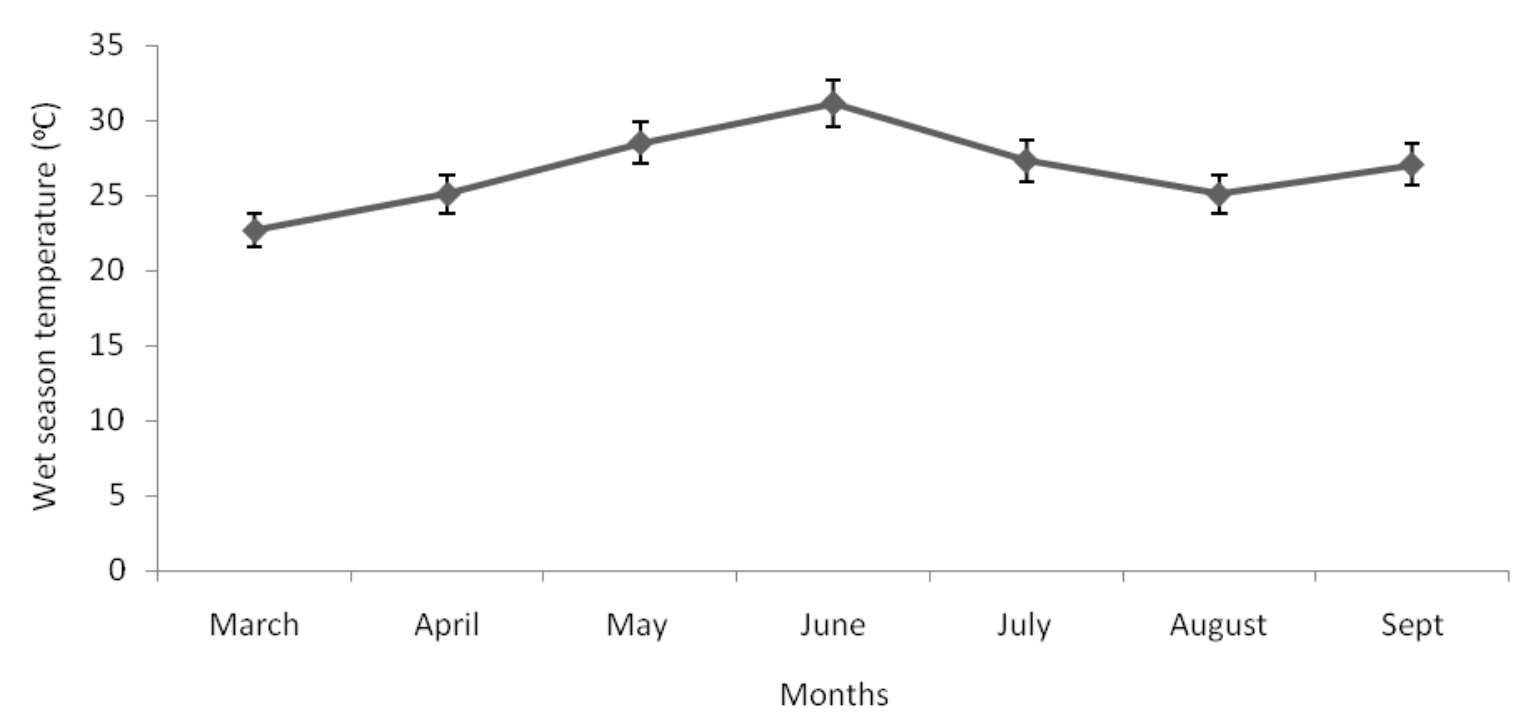

Figure 1d. Wet conditions during the conduct of the experiment in 2016

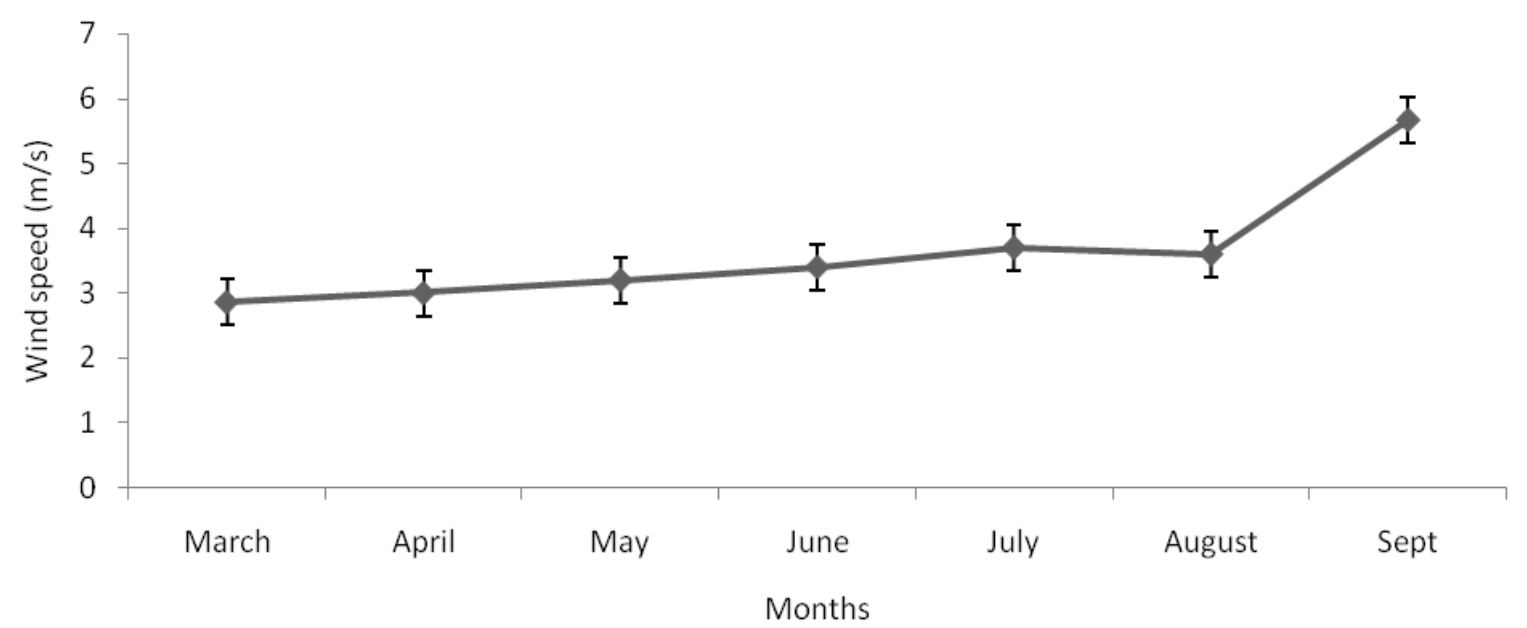

Figure 1e. Wind speed conditions during the conduct of the experiment in 2016

\section{Results and discussion}

\section{Plant height at maturity (cm)}

Plant height is a significant component of the leaves and yield as well as of sesame seed mass production ability because it involves major photosynthate translocation from the roots and lower parts to the aerial parts of the plant. Hereditary characteristics of genotypes typically and environmental factors significantly influence plant height. Plant height at maturity (Table 2) was statistically significant. The third sowing date (15 April 2016) gave maximum plant height $(95.44 \mathrm{~cm})$, which was followed by the 2 nd sowing date (1 April 2016).
The lowest plant height (92.33 a) was found for the 1st sowing date (15 March 2016). Genotype of sesame also produced significant results, as given in Table 2 . The sesame variety ( $\mathrm{SV}_{1}=$ 'TS-5') produced maximum plant height $(100 \mathrm{~A})$ at the time of maturity, and this trend of height (92 B) was followed by $\mathrm{SV}_{2}=$ 'TH6'. Low plant height (89.67 B) was observed in $\mathrm{SV}_{3}=$ '4002', as shown in Table 2 . Therefore, the gradual increase in temperature and changes in photoperiod enhanced plant height, which was also strongly influenced by planting intervals. These results are closely related to the findings of Tahir et al. (2012). The interaction among the sowing dates and sesame varieties was found to be non-significant, as shown in Table 2 . 
Table 2

Impact of sowing date and sesame cultivar on plant height at maturity $(\mathrm{cm})$

\begin{tabular}{|l|c|c|c|c|}
\hline Varieties & \multicolumn{3}{|c|}{ Sowing date } & Mean \\
\hline & $\begin{array}{c}\mathrm{S}_{1}=1 \text { 1st sowing (15 March } \\
2016)\end{array}$ & $\begin{array}{c}\mathrm{S}_{2}=2 \text { 2nd sowing (1 April } \\
2016)\end{array}$ & $\begin{array}{c}\mathrm{S}_{3}=\text { 3rd sowing (15 } \\
\text { April 2016) }\end{array}$ & $100 \mathrm{~A}$ \\
\cline { 2 - 5 } $\mathrm{SV}_{1}=\mathrm{TS}-5$ & 95.66 & 99.00 & 105.33 & $92 \mathrm{~B}$ \\
\hline $\mathrm{SV}_{2}=\mathrm{TH}-6$ & 88.33 & 93.66 & 94.00 & $89.67 \mathrm{~B}$ \\
\hline $\mathrm{SV}_{3}=4002$ & 87.00 & 93.00 & 89.66 & \\
\hline Mean & $92.33 \mathrm{a}$ & $93.889 \mathrm{a}$ & $95.444 \mathrm{a}$ & \\
\hline
\end{tabular}

Where all the values having two different letters (A, B OR a, b) showed statistically significant difference at > 0.05 probability level For sowing dates and sesame varieties

Standard Error for Comparison 1.8749

Critical Value for Comparison 3.9747

\section{Number of capsules per plant}

Data in Table 3 showed that number of capsules per plant was highly significant. The first sowing date (15 March 2016) gave the highest number of capsules per plant (88.0 a), which was followed by $(71.33 \mathrm{~b})$ at the 3rd sowing date (15 April 2016). The smallest number of capsules per plant (50.33 c) was found for the 2nd sowing date (1 April 2016). Sesame varieties also established very significant results, as given in Table 3. SV $_{1}=$ 'TS-5' produced the greatest number of capsules per plant $(61.22 \mathrm{~A})$, followed by $\mathrm{SV}_{2}={ }^{\prime} \mathrm{TH}-$ 6 '. The lowest number of capsules per plant was counted (46 B) in $\mathrm{SV}_{3}=4002$. The variation in number of capsules among sesame genotypes was due to morphological characters. This might explain the reliable differences between the tested cultivars in all growth parameter. Gradual increase in temperature and photoperiod improved the number of capsules per plant; on the other hand, planting intervals also gave a significant contribution to the high number of capsules per plant. Similar results were reported by Ahmad et al. (2001); Akbar et al. (2012); Ansah et al. (2015); Abebe and Workayehu (2015). The interaction among the sowing dates and sesame varieties was found to be non-significant, as shown in Table 3.

Table 3

Impact of sowing date and sesame cultivar on the number of capsules per plant

\begin{tabular}{|l|c|c|c|c|}
\hline Varieties & \multicolumn{3}{|c|}{ Sowing date } \\
\hline & $\begin{array}{c}\mathrm{S}_{1}=\text { 1st sowing (15 March } \\
2016)\end{array}$ & $\begin{array}{c}\mathrm{S}_{2}=\text { 2nd sowing (1 April } \\
2016)\end{array}$ & $\begin{array}{c}\mathrm{S}_{3}=\text { 3rd sowing (15 } \\
\text { April 2016) }\end{array}$ & Mean \\
\cline { 2 - 5 } $\mathrm{SV}_{1}=\mathrm{TS}-5$ & 45.00 & 51.33 & 87.33 & $61.22 \mathrm{~A}$ \\
\hline $\mathrm{SV}_{2}=\mathrm{TH}-6$ & 24.66 & 49.33 & 64.00 & $46.00 \mathrm{~B}$ \\
\hline $\mathrm{SV}_{3}=4002$ & 68.00 & 50.33 & 62.66 & $60.33 \mathrm{~A}$ \\
\hline Mean & $88.0 \mathrm{a}$ & $50.33 \mathrm{c}$ & $71.33 \mathrm{~b}$ & \\
\hline
\end{tabular}

Where all the values having two different letters (A, B OR a, b) showed statistically significant difference at $>0.05$ probability level For sowing dates and sesame varieties

Standard Error for Comparison 1.8749

Critical Value for Comparison 3.9747

\section{Number of seeds per capsule}

Number of seeds per capsule is the major yield contributing trait. Its cumulative values indicate maximum yield of plants depending on the morphological and genetic characters of the cultivars. Number of seeds per capsule (Table 4) was influenced significantly. Data showed that the 2 nd sowing date (1 April 2016) gave the highest number of seeds per capsule (53.88 a ), followed by the 3rd sowing date (15 April 2016) (51.11 b). The lowest number of seeds per capsule per plant (50.22 b) was noted for the $1^{\text {st }}$ sowing date (15 March 2016), which was also statistically at par with $S_{3}$. As regards sesame genus diversity, sesame varieties also produced a significant result, as given in Table $4 . \mathrm{SV}_{1}={ }^{\prime} \mathrm{TS}-5$ ' gave maximum seeds per capsule $(64 \mathrm{~A})$, followed by $\mathrm{SV}_{2}=$ 'TH-6'. The lowest (49.11B) number of seeds per capsule per plant was obtained in $\mathrm{SV}_{3}=$ '4002'. The results are in agreement with those of Fazli et al. (2008); Ehsanullah et al. (2007) and Ravusaheb et al. (2010).

The regular increase in temperature and photoperiod enhanced the number of seeds per capsule in all sesame genotypes, and planting intervals strongly influenced the sesame varieties. Bedigian et al. (1986), and Abebe and Workayehu (2015) showed analogous results. The interaction among the sowing dates and sesame varieties was found to be non-significant, as shown in Table 4. 
Table 4

Impact of sowing date and sesame cultivar on the number of seeds per capsule

\begin{tabular}{|c|c|c|c|c|}
\hline Varieties & \multicolumn{4}{|c|}{ Sowing date } \\
\hline \multirow[b]{2}{*}{$\mathrm{SV}_{1}=\mathrm{TS}-5$} & $\begin{array}{c}\mathrm{S}_{1}=1 \text { st sowing (15 March } \\
\text { 2016) }\end{array}$ & $\begin{array}{c}S_{2}=2 \text { nd sowing (1April } \\
\text { 2016) }\end{array}$ & $\begin{array}{c}S_{3}=\text { 3rd sowing }(15 \\
\text { April 2016) }\end{array}$ & Mean \\
\hline & 51.66 & 54.66 & 85.66 & $64.00 \mathrm{~A}$ \\
\hline $\mathrm{SV}_{2}=\mathrm{TH}-6$ & 60.00 & 50.66 & 49.66 & $53.44 \mathrm{~B}$ \\
\hline $\mathrm{SV}_{3}=4002$ & 39.00 & 56.33 & 52.00 & $49.11 \mathrm{~B}$ \\
\hline Mean & $50.22 \mathrm{~b}$ & $53.88 \mathrm{a}$ & $51.11 \mathrm{~b}$ & \\
\hline
\end{tabular}

Where all the values having two different letters (A, B OR a, b) showed statistically significant difference at $>0.05$ probability level

Standard Error for Comparison $1.8749 \quad$ Critical Value for Comparison 3.9747

\section{Seed weight tha-1}

Seed weight is the cumulative outcome of yield contributing parameters in general, but the genotypic characteristic in relation to planting time can enhance the yield. Significant data was found for sowing dates in case of seed weight, as given in Table 5 . The 3rd sowing date (15 April 2016) gave maximum seed weight $(0.96$ a), followed by the 2 nd sowing date (1 April 2016). The lowest seed weight $t$ ha $^{-1}(0.7 \mathrm{~b})$ was recorded at the 1st sowing date (1 March 2016). The effect of sesame varieties was very significant (Table 5 ). $\mathrm{SV}_{1}={ }^{\prime} \mathrm{TS}-5^{\prime}$ gave the highest seed weight $(0.86 \mathrm{~A})$, followed by $\mathrm{SV}_{2}=$ 'TH6'. Minimum seed weight $(0.76 \mathrm{C})$ was observed in $\mathrm{SV}_{3}=$ '4002'. Slowly but surely, increasing temperature and photoperiod enhanced seed weight $\left(t \mathrm{th}^{-1}\right)$, and sesame sowing dates and varieties are also paly a significant role.. These findings are in agreement with Noorka et al. (2011); Ansah (2015) \& Blal et al. (2012). The interaction among the sowing dates and sesame varieties was found to be non-significant, as shown in Table 5.

Table 5

Impact of sowing date and sesame cultivar on seed weight $t$ ha-1

\begin{tabular}{|c|c|c|c|c|}
\hline Varieties & \multicolumn{4}{|c|}{ Sowing date } \\
\hline \multirow[b]{2}{*}{$\mathrm{SV}_{1}=\mathrm{TS}-5$} & $\begin{array}{c}\mathrm{S}_{1}=1 \text { st sowing (15 March } \\
\text { 2016) }\end{array}$ & $\begin{array}{c}\mathrm{S}_{2}=\text { 2nd sowing (1 April } \\
\text { 2016) }\end{array}$ & $\begin{array}{c}\mathrm{S}_{3}=\text { 3rd sowing }(15 \\
\text { April 2016) }\end{array}$ & Mean \\
\hline & 0.7 & 0.9 & 1.0 & $0.86 \mathrm{~A}$ \\
\hline $\mathrm{SV}_{2}=\mathrm{TH}-6$ & 0.8 & 0.8 & 0.9 & $0.83 \mathrm{~B}$ \\
\hline $\mathrm{SV}_{3}=4002$ & 0.6 & 0.7 & 1.0 & $0.76 \mathrm{C}$ \\
\hline Mean & $0.7 \mathrm{c}$ & $0.8 \mathrm{~b}$ & $0.96 \mathrm{a}$ & \\
\hline
\end{tabular}

Where all the values having two different letters (A, B OR a, b) showed statistically significant difference at > 0.05 probability level

For sowing dates and sesame varieties

Standard Error for Comparison $0.1925 \quad$ Critical Value for Comparison 0.4080

\section{Number of leaves per plant}

The effect of sowing dates on the number of leaves per plant (Table 6) was highly significant. The $3^{\text {rd }}$ sowing date (15 April 2016) gave the maximum number of leaves per plant (105.11 a), followed by the 2nd sowing date (1 April 2016) (101.00 b). The lowest number of leaves per plants (91.33 c) was observed at the $1^{\text {st }}$ sowing date (15 March 2016). The effect of sesame varieties was also significant (Table 6). $\mathrm{SV}_{1}=$ 'TS-5' had the highest number of leaves per plant $(110.67 \mathrm{~A})$, followed by $\mathrm{SV}_{3}=$ '4002', while the lowest number of leaves per plant $(88.11 \mathrm{C})$ was found in
$\mathrm{SV}_{2}=$ 'TH-6'. With increasing temperature and photoperiod, the number of leaves per plant was increased. Leaves are a major contributor to plant yield, and they play a role in photosynthesis. In addition to other factors such as leaf position and leaf area, number of leaves is basically closely related to cultivar type, and is enhanced by favorable environment and planting time. These results are in agreement with the findings reported by Uzun and Cagirgan (2006); Malik et al. (2003) \& Ravusaheb et al. (2010). The interaction among the sowing dates and sesame varieties was found to be non-significant, as shown in Table 6.

\section{Table 6}

Impact of sowing date and sesame cultivar on number of leaves per plant

\begin{tabular}{|c|c|c|c|c|}
\hline Varieties & \multicolumn{4}{|c|}{ Sowing date } \\
\hline & $\begin{array}{c}\mathrm{S}_{1}=1 \text { st sowing (15 March } \\
\text { 2016) }\end{array}$ & $\begin{array}{c}\mathrm{S}_{2}=2 \text { 2nd sowing (1 April } \\
\text { 2016) }\end{array}$ & $\begin{array}{c}\mathrm{S}_{3}=\text { 3rd sowing }(15 \\
\text { April 2016) }\end{array}$ & Mean \\
\hline $\mathrm{SV}_{1}=\mathrm{TS}-5$ & 102 & 116 & 114 & $110.67 \mathrm{~A}$ \\
\hline $\mathrm{SV}_{2}=\mathrm{TH}-6$ & 79.66 & 88.33 & 96.33 & $88.11 \mathrm{C}$ \\
\hline $\mathrm{SV}_{3}=4002$ & 92.33 & 98.66 & 105.00 & $98.67 \mathrm{~B}$ \\
\hline Mean & $91.33 \mathrm{c}$ & $101.00 \mathrm{~b}$ & $105.11 \mathrm{a}$ & \\
\hline
\end{tabular}

Where all the values having two different letters (A, B OR a, b) showed statistically significant difference at $>0.05$ probability level For sowing dates and sesame varieties Standard Error for Comparison 1.9274 


\section{Stem diameter}

Comparisons of sowing dates data showed that stem diameter (Table 7) was statistically significant. The $3^{\text {rd }}$ sowing date (15 April 2016) produced the highest stem diameter (16.89 a), followed by the 2 nd sowing date (1 April 2016). The lowest stem diameter $(15.17 \mathrm{~b})$ was recorded for the 1 st sowing date $(15$ March 2016). Similarly, the effect of sesame genotypes also confirmed significant results, as given in Table 7 . $\mathrm{SV}_{1}=$ 'TS-5' generated the highest stem diameter $(17.36$ A), followed by $\mathrm{SV}_{2}=$ ' $\mathrm{TH}-6$ ' while minimum stem diameter (15.01B) was found in $\mathrm{SV}_{3}=$ '4002'. The gradual increase in temperature and day length hours enhanced stem diameter both in case of planting intervals and sesame varieties. These results corroborate the findings of Malik et al. (2003); Fazli et al. (2010); Saleem et al. (2008); Ehsanullah et al. (2007); Ansah (2015); Blal et al. (2012) and Ravusaheb et al. (2010), who also reported similar effects on stem diameter. The interaction among the sowing dates and sesame varieties was found to be non-significant, as shown in Table 7.

\section{Table 7}

Impact of sowing date and sesame cultivar on stem diameter

\begin{tabular}{|l|c|c|c|c|}
\hline Varieties & \multicolumn{3}{|c|}{ Sowing date } \\
\hline & $\mathrm{S}_{1}=1$ st sowing (15 March & $\mathrm{S}_{2}=$ 2nd sowing (1 April & $\mathrm{S}_{3}=$ 3rd sowing (15 \\
April 2016) & Mean \\
\cline { 2 - 5 } & $2016)$ & $2016)$ & 18.27 & $17.36 \mathrm{~A}$ \\
\hline $\mathrm{SV}_{1}=\mathrm{TS}-5$ & 16.90 & 17.90 & 15.43 & $15.01 \mathrm{~B}$ \\
\hline $\mathrm{SV}_{2}=\mathrm{TH}-6$ & 13.96 & 14.97 & 16.30 & $15.60 \mathrm{~B}$ \\
\hline $\mathrm{SV}_{3}=4002$ & 14.63 & 15.87 & $16.89 \mathrm{a}$ & \\
\hline Mean & $15.17 \mathrm{~b}$ & $15.91 \mathrm{ab}$ & \\
\hline
\end{tabular}

Where all the values having two different letters (A, B OR a, b) showed statistically significant difference at > 0.05 probability level For sowing dates and sesame varieties Standard Error for Comparison 0.4724 Critical Value for Comparison 1.0014

\section{Productive capsules per plant}

Number of productive capsules per plant was also found to be significant in sesame for different sowing dates, as mentioned in Table 8. Maximum number of productive capsules per plant (75.33 a) was found for the $3^{\text {rd }}$ sowing date (15th April 2016), followed by the 2nd sowing date (1April 2016). The lowest number of productive capsules per plant $(40.00 \mathrm{~b})$ was observed for the 1st sowing date (15 March 2016). Similarly, the effect of sesame varieties also confirmed significant results, as given in Table 8 .

Table 8:

Impact of sowing date and sesame cultivar on productive capsules per plant

\begin{tabular}{|l|c|c|c|c|}
\hline Varieties & \multicolumn{3}{|c|}{ Sowing date } \\
\hline \multirow{3}{*}{$\mathrm{SV}_{1}=\mathrm{TS}-5$} & $\begin{array}{c}\mathrm{S}_{1}=1 \text { 1st sowing (15 March } \\
2016)\end{array}$ & $\begin{array}{c}\mathrm{S}_{2}=2 \text { 2nd sowing (1 April } \\
2016)\end{array}$ & $\begin{array}{c}\mathrm{S}_{3}=\text { 3rd sowing }(15 \\
\text { April 2016) }\end{array}$ & Mean \\
\cline { 2 - 5 } & 42.00 & 78.33 & 76.33 & $65.56 \mathrm{~A}$ \\
\hline $\mathrm{SV}_{2}=\mathrm{TH}-6$ & 22.00 & 64.33 & 71.00 & $52.44 \mathrm{~B}$ \\
\hline $\mathrm{SV}_{3}=4002$ & 56.00 & 59.00 & 78.66 & $64.56 \mathrm{~A}$ \\
\hline Mean & $40.00 \mathrm{~b}$ & $67.22 \mathrm{a}$ & $75.33 \mathrm{a}$ & \\
\hline
\end{tabular}

Where all the values having two different letters (A, B OR a, b) showed statistically significant difference at $>0.05$ probability level For sowing dates and sesame varieties

Standard Error for Comparison $4.1665 \quad$ Critical Value for Comparison 8.8327

Maximum number of productive capsules per plant $(65.56 \mathrm{~A})$ was obtained by $\mathrm{SV}_{1}={ }^{\prime} \mathrm{TS}-5^{\prime}$, , followed by $\mathrm{SV}_{2}={ }^{\prime} \mathrm{TH}-6^{\prime}$. Minimum number of productive capsules per plant (52.44B) was found in $\mathrm{SV}_{3}=$ '4002'. These results confirm the findings of Malik et al. (2003) and Bhatti and Nazir (2005). The result proved that, If sowing dates changed, the competition among the genotypes increased particularly in yield traits of sesame like productive capsule. Gradually increasing temperature and photoperiod enhanced the productive capsule per plant in case sesame cultivation. The interaction among the sowing dates and sesame varieties was found to be non-significant, as shown in ) Table 8.

\section{Unproductive capsules per plant}

Statistically non-significant results were found in Table 9 for unproductive capsules per plant for different sowing dates. It may be due to early production of capsules, which produced no seed. The effect of sesame varieties also confirmed very significant results, as given in Table 9. The sesame variety $\mathrm{SV}_{3}=$ '4002' produced unproductive capsules per plant $(5 \mathrm{~A})$, and the result was at par (3B) with $\mathrm{SV}_{1}=$ 'TS-5'. Number of unproductive capsules per plant in ' $\mathrm{TH}-5$ ' and $\mathrm{SV}_{2}=$ ' $\mathrm{TH}-6$ ' was statistically at par with each other. Although the number of capsules was higher in $\mathrm{SV}_{3}=$ '4002' genotype, it failed to change in economic index. It might be due to environmental conditions and change in planting season in comparison to the other cultivars in the same situations. Sesame genotypes were strongly influenced in unproductive capsule development regardless of sowing date. Many scientists (Ehsanullah et al., 2007; Ansah., 2015; Blal et al., 2012 and Ravusaheb et al., 2010) also reported similar results on the number of unproductive capsules per plant in sesame. The interaction among the sowing dates and sesame varieties was found to be non-significant, as shown in Table 9. 
Table 9

Impact of sowing date and sesame cultivar on unproductive capsules per plant

\begin{tabular}{|l|c|c|c|c|}
\hline Varieties & \multicolumn{3}{|c|}{ Sowing dates } \\
\hline & $\begin{array}{c}\mathrm{S}_{1}=1 \text { st sowing (15 March } \\
2016)\end{array}$ & $\begin{array}{c}\mathrm{S}_{2}=2 \text { 2nd sowing (1April } \\
2016)\end{array}$ & $\begin{array}{c}\mathrm{S}_{3}=\text { 3rd sowing (15 } \\
\text { April 2016) }\end{array}$ & Mean \\
\cline { 2 - 5 } $\mathrm{SV}_{1}=\mathrm{TS}-5$ & 3.00 & 5.33 & 4.33 & $4.22 \mathrm{AB}$ \\
\hline $\mathrm{SV}_{2}=\mathrm{TH}-6$ & 2.66 & 2.66 & 3.66 & $3.00 \mathrm{~B}$ \\
\hline $\mathrm{SV}_{3}=4002$ & 5.00 & 4.00 & 6.00 & $5.00 \mathrm{~A}$ \\
\hline Mean & $3.56 \mathrm{~ns}$ & $4.00 \mathrm{~ns}$ & $4.67 \mathrm{~ns}$ & \\
\hline
\end{tabular}

Where all the values having two different letters (A, B OR a, b) showed statistically significant difference at $>0.05$ probability level ns = non-significant For sowing dates and sesame varieties

Standard Error for Comparison $0.7831 \quad$ Critical Value for Comparison 1.6600

\section{Conclusion}

Under prevailing agro-climatic conditions of the Lasbela District, the research results showed that maximum seed production was attained by the sesame variety 'TS-5' as compared to the other two sesame varieties ('TH-6' and '4002'). Sowing sesame on 15 April 2016 was more economic as compared to the other planting dates. Climatic conditions are favorable for sesame cultivation, especially for 'TS-5'.

\section{References}

Abebe, B., Workayehu, T. (2015). Effect of method of sowing and time ammonium phosphate (DAP) fertilizer application, on yield and yield components of tef (eragrostictef) trotter) at Shebedino, southern Ethiopia. Advances in Crop Science and Technology, 3(2), 1-7.

Abeje, A., Mihretu, A., Abebaw, L., Desalegn, T., Awoke, M., Ayen, K. (2016). Participatory evaluation of hybrid sorghum technologies: In mid and low land areas of Wag Himra zone, Eastern Amhara, Ethiopia. Journal of Agricultural Extension and Rural Development, 8(5), 8088.

Ahrnad, A., Akhtar, M., Hussain A., Ehsanullah, Musaddique, M. (2001). Genotypic response of sesame to nitrogen and phosphorus application. Pakistan Journal of Agricultural Sciences, 38, 1-2.

Akbar, F., Yousaf, N., Ashiq, R. M., Khan S., Shahid,.Z., Masood, M. (2012). Study of total seed proteins pattern of sesame (Sesamum Indicum L.) landraces via sodium dodecyl sulfate polyacrylamide gel elecrophoresis (SDS-PAGE). Pakistan Journal of Botany, 44, 2009-2014.

Ali, S., Jan, A. (2014). Sowing dates and nitrogen level effect on yield and yield attributes of sesame cultivars. Sarhad Journal of Agriculture, 30(2), 204-209.

Anandkumar, Pandian (2001): Studies on heterosis and character association in sesame. Advances in Agriculture Research, 15, 226-228.

Ansah, K. D., Sintim, H. O., Awuah, S., Ali, J. E., Oteng, G. (2015). The adoption of temperate selected sesame accessions in the tropics selected for Japan and grown in Ghana. Journal of Agricultural Sciences, 7(5), 47-55.

Ball, R.A., Purcell L.C., Vories, E.D. (2000). Short-season soybean yield compensation in response to population and water regime. Crop Science, 40, 1071-1078.

Bhardwaj, H.L., Hamama, A.A., Kraemer, M.E., Langham, D.R. (2014). Cultivars, planting dates and row spacing effects on sesame seed yield and mineral composition. Journal of Agriculture Science, 6(9), 1-7.

Bedigian, D., Harlan, J.R. (1986). Evidence for cultivation of sesame in the ancient world. Economic Botany, $40(2), 137-154$.

Bhatti, I.H., Nazir, M.S. (2005). Agronomic Traits of Sesame as Affected by Grain Legumes Intercropping and Plating Patterns. Pakistan Journal of Agricultural Sciences, 42, 5660.
Blal, A.H.S., Kamel, M., Mahfouz, H.M., El Wahed, M.S.A. (2012). Impact of pollination and fertilization on sesame (Sesamum indicum L.) production in the reclaimed land islamilia. Egyptian Journal of Agriculture Sciences, 57(3), 121-133.

Boureima, S., Eyletters, M., Diouf, M., Diop, T.A., Damme, P. V. (2011). Sensitivity of germination and seeding radical growth to drought stress in sesame (Sesamum indicum L.). Research Journal of Environmental Science, 5(6), 557564

Chongdar, S., Singharoy, A., Saha, A., Chhetri, B. (2015). Performance of summer sesame (Sesamum indicum L.) cultivars under varying dates of sowing in prevailing agro-climatic condition of North Bengal. Scientific Research and Essays, 10(12), 411-420.

De, P.S., Bhale, V.M., Khadse, V.A. (2013). Quality and economics of summer sesame (Sesamum indicum L.) as influenced by irrigation and nutrient levels. International Journal of Bio-resource and Stress Management, 4(2), 369371.

Ehsanullah, Akbar, N., Iqbal, A., Mohsin, M.R. (2007). Effect of different planting patterns on the growth and yield of two varieties of sesame. Pakistan Journal of Agriculture Science, 44(4), 584-586.

FAO. (2013). FAOSTAT database, Food and Agriculture Organization of the United Nation, Rome, Italy. http://faostat3.fao.org/browse/Q/QC/E.

Fazli, I.S., Jamal, A., Ahmad, S., Masoodi, S.,Khan, J.S., Abdin M.Z. (2008). Interactive effect of sulphur and nitrogen on nitrogen accumulation and harvest in soil seed crops differing in nitrogen assimilation potential. Journal of Plant Nutrition, 31, 1203-1220.

Fazli, I.S., S., Masoodi, S., Khan, J.S. \& Abdin M.Z. (2010). Interactive effect of sulphur and nitrogen on growth and yield attributes of oilseed crops. Journal of Plant Nutrition, 33, 1216-1228.

Gebre, H. (2006). The effect of planting methods and spacing on the yield and yield attributes of Sesame (Sesamum indicum L.) in the lowland plain of Humera, Western Tigray, Ethiopia. Haramaya University, Haramaya, Ethiopia.http://213.55.85.90/bitstream/handle/123456 $789 / 682$.

Government of Pakistan. 2014. Economic Survey of Pakistan. G ovt. of Pakistan, Finance and Economic Affairs Division, Is lamabad, Pakistan.pp 23 44. http://www.finance.gov.pk/ survey/chapters 15/02 Agricultre.pdf.

Grichar, W. J., Sestak, D. C. Brewer, K. D., Besler, B. A., Stichler, C. R., \& Smith, D.

T. (2001). Sesame (Sesamum indicum L.) tolerance and weed control with soil-applied herbicides. Crop Protection, 20 (5), 389-394.

Hamza, M., Abd El-Salam, R.M. (2015). Optimum planting date for three sesame cultivars growing under sandy soil conditions in Egypt. American-Eurasian Journal of Agriculture and Environmental Science, 15(5), 868-877.

Haruna, M. (2011). Growth and yield of sesame (Sesamum indicum L.) as affected by poultry manure, nitrogen and phosphorus at Samaru, Nigeria. Journal of Animal and Plant Science, 21(2), 653-659.

Jan, A., Ali, S., Inamullah, Ahmad, M. (2014). Influence of sowing time and nitrogen fertilization on alter aria leaf 
blight and oil yield of sesame cultivars. Pure and Applied Biology, 3(4), 160-166.

Malik, M., Saleem, M.F., Cheema, M.A., Ahmed, S. (2003). Influence of different nitrogen levels on productivity of sesame (Sesamum indicum L.) under varying planting patterns. International Journal of Agriculture and Biology, 5(4), 490-492.

Mkamil, G.S., Bedigian, D. (2007). The effect of spacing and fertilizer application on the growth, yield and yield components of sesame (Sesamum indicum L.). Agriculture Husbandry, 53, 355-375.

Nantongo, S. (2002). Effect of spatial arrangement and plant population on growth and yield of sesame (Sesamum indicum L.) in pure stands and in mixtures with finger millet. Dissertation for Award of M.Sc. Degree at Makerere University, Kampala, Uganda, 3538. http://suaire.suanet.ac.tz:8080/xmlui/bitstream/handle $/ 123456789 / 482$

Ngala, A. L., Dugje, I. Y., Yakubu, H. (2013). Effects of inter-row spacing and plant density on performance of sesame (Sesamum indicum L.) in a Nigerian Sudan Savanna. Science International (Lahore), 25(3), 513-519.

Noorka, I.R., Hafiz, S.I., El-Bramawy, M.A.S. (2011). Response of sesame to population densities and nitrogen fertilization on newly reclaimed sandy soils. Pakistan Journal of Botany, 43(4), 1953- 1958.

Olowe, V.I., Adeoniregun, O.A. (2010). Seed yield, yield attributes and oil content of newly released sesame (Sesamum indicum L.) varieties. Archives of Agronomy and Soil Science, 56, 201-210.
Onsaard, E. (2012). Sesame proteins. International Food Research Journal, 19(4), 1287-1295.

Ravusaheb, M., Babalad, H., Kumara, B. H. P., Pushpa, V. (2010). Effect of organics and fermented organics on yield, soil available $\mathrm{N}, \mathrm{P}_{2} \mathrm{O}_{5}, \mathrm{~K}_{2} \mathrm{O} \mathrm{kg} \mathrm{ha}^{-1}$ and microbial count in sesame. American Journal of Soil Science, 5(2), 379-385.

Saleem, M.F., Malik, M.A., Cheema, M.A., Wahid, M.A. (2008). Yield and Quality Response of Sesame (Sesamum indicum L.) to Irrigation Frequencies and Planting Patterns. Canadian Journal of Plant Science, 88, 101-109.

Steel, R.G.D., Torrie, J.H., Dicky, D.A. (1997). Principles and pro cedures of Statistics. A biometrical Approach 3rd Ed. McGraw Hill Book Co. Inc. New York, 400-428.

Tahir, M.U., Saeed, A.A., Hassan, I., Naeem, M., Ibrahim, M., Rehman, H., Javeed, H.M.R. (2012).Optimizing sowing date and row spacing for newly evolved sesame (Sesamum indicum L.) variety TH-6. Pakistan Journal of Life and Social Science, 10(1),1-4.

Tsehay, E. (2006). Manual for sesame production and marketing. Ministry of Agriculture and Rural Development. Advances in Agriculture Economics, 20, 98106.

Uzun, B., Cagirgan, M.I. (2006) Comparison of determinate and indeterminate lines of sesame for agronomic traits. Field Crops Research, 96, 13-18.

Wei, L. B., Zhang, H.Y., Zheng, Y.Z., Guo, W.Z., Zhang, T.Z. (2008). Development and utilization of EST-derived microsatellites in sesame (Sesamum indicum L.). Acta Agronomica Sinica, 34, 2077-2084. 